JOURNAL OF SECURITY AND SUSTAINABILITY ISSUES ISSN 2029-7017 print/ISSN 2029-7025 online

2019 December Volume 9 Number 2

http://doi.org/10.9770/jssi.2019.9.2(6)

Scopus

\title{
ANTECEDENTS OF ECONOMIC CONVERGENCE IN ASEAN COUNTRIES: FOREIGN DIRECT INVESTMENT, TRADE, GOVERNMENT SIZE, POPULATION AND ECONOMIC CONVERGENCE
}

\author{
Marlina Widiyanti ${ }^{1}$, Ernie Hendrawaty ${ }^{2}$ Djawoto $^{3}$ \\ ${ }^{I}$ Faculty of Economics, Universitas Sriwijaya, Palembang, Indonesia. \\ ${ }^{2}$ Faculty of Economics and Business, Universitas Lampung, Bandar Lampung, Indonesia. \\ ${ }^{3}$ Faculty of Management, Indonesia School of Economics Surabaya, Surabaya, Indonesia. \\ E-mails: ${ }^{1}$ marlinawidiyanti68@yahoo.co.id (corresponding author)
}

Received 25 February 2019; accepted 10 October 2019; published 30 December 2019

\begin{abstract}
The main objective of the currents study is to investigate and explore the antecedents of the convergence in ASEAN countries. Foreign direct investment, trade, government size, population are examined as the antecedents of the economic convergence in ASEAN countries. Examining the phenomena of absolute convergence among ASEAN countries is another set goal of this research. Achieving this goal obviously requires different approach, methodology wise. Cross section regression-based studies have utilized what is called 'regression to mean' to examine absolute convergence across countries traditional unit root testing procedure developed by Dickey and Fuller (1979) is employed to test for convergence hypothesis. Employing ADF test also serves two purposes: 1) the methods has to be used to provide input for performing simulations to apply SURADF procedure. Developed by Blundell and Bond (1998), system GMM uses additional moment conditions to serve as an improvement in terms of performance of estimators in the models developed in Arellano and Bond (1991). The implication of this finding is that economies that are more open in terms of trade and with high level of government participation are more likely to show high level of convergence to the group average real GDP per capita than economies that less open to trade with little government participation as measured by government final consumption expenditure as a percentage of GDP.
\end{abstract}

Keywords: economic convergence; trade, ASEAN

Reference to this paper should be made as follows: Widiyanti, M., Hendrawaty, E., Djawoto. 2019. Antecedents of economic convergence in asean countries: foreign direct investment, trade, government size, population and economic convergence, Journal of Security and Sustainability Issues 9(2): 431-445. http://doi.org/10.9770/jssi.2019.9.2(6)

JEL Classifications: F23, F1

\section{Introduction}

Foreign capital attraction capacity of developing countries is another issue that has been largely scrutinized. According to Adhikary (2017), although there is 'dramatic increase' in the level of FDI flows into developing countries, the distribution of such capital is highly skewed in favour of a limited number of such countries. With the view to investigate on the determinants of capital attraction capacity of countries, Boateng, Hua, and Nisar (2015) utilized data on eight determinants of FDI inflow for a sample of 138 countries. Results emanating from the work of Boateng et al. (2015); Bayham, (2016) turnout to provide a justification for what Adhikary (2017) observed. According to Boateng et al. (2015), level of inward FDI inflow into a particular country depends positively on the level of development, trade openness as well as low risk. The researchers therefore prescribed for developing economies putting in place policies that would focus on enhancing physical, legal and political environment alongside trade openness. In a similar research carried out on 29 Chinese regions, reported regions with relatively larger size of market tend to attract more FDI inflows than ones with relatively smaller size of 
market. Moreover, regional infrastructural development was identified to have direct link with the FDI inflows attraction capacity of a region. However, the researchers identified wage cost of labour as having negative link with the inward FDI of the regions. In a more recent study by Kurul (2017), on emerging market economics, political instability, high corporate income tax rates and trade tariffs are negatively related to inward FDI.

One of the underlying assumptions associated with support for foreign capital is that it has the capacity to facilitate bridging 'idea gap' between rich and poor countries. Moreover, Oduro (2016) emphasized on the role of technology adoption via human capital accumulation and international trade as an important determinant of output growth in developing nations. Considering the role of FDI in bridging technology diffusion, employment generation and skills acquisition, poor countries are more in need of FDI than the richer ones. According to Adhikary (2017); Bayham, (2016), less developed countries place higher hope on FDI inflows to pave their ways in alleviating skills and resource constraints. Moreover, the authors observed that the trend of FDI flows across the world is highly skewed in favour of very few countries that provide certain combination of locational advantages.

Looking at the trend of FDI inflows across the globe, it is apparent that while each developing continent enjoys upsurge in its share of FDI inflows, the gap among regions, sub regions and individual countries remains wide. For example, development indicators database of World Bank (2014) reveals that during 1986 - 1990 net FDI inflows to East Asia and Pacific and SSA stood at $\$ 71.72$ billion and $\$ 5.65$ billion, respectively. As for the global FDI inflows, the database reveals that for the period 2006 - 2010, low-income economies' share of the allocation accounts for a meager value 0.54 percent, this compares with 5.56 percent for lower middle-income category. While the share of upper-middle-income countries stood at 21.34 percent, that of high-income economies is 72.56 percent.

Studies linking FDI inflows and economic growth (ECG) are quite numerous, such as Flora and Agrawal (2017) and (Doytch \& Narayan, 2016). There are also several studies conducted on the determinants of FDI inflows. Such studies include Adhikary (2017) and Boateng et al. (2015). While some of these studies utilized time series data some used panel data. However, there are too few studies conducted to access the extent to which divergence in FDI allocation and distribution among countries of a particular region affect ECG and convergence (Simionescu, 2016; Bosupeng, 2018).However, few studies conducted on the link between FDI and economic convergences suffers a number of weaknesses. For instance, the work of Simionescu (2016) employs traditional panel date tools that have inherent weakness of inability to handle the endogeneity problem. As a remedy, the existing study employs dynamic panel data method in the form of system GMM. In addition, the study pooled data from both developed and developing economies. By pooling data from both developed and developing economies, the study does not show clearly the impact of FDI inflow on the per capita income convergence of developing economies to the real GDP per capita of developed economies. The current study therefore addresses the problem identified with the work of Simionescu (2016); Boutayeba, (2017).

There are several studies conducted on the process of convergence in the economy. Most of the previous research studies are based on the emerging economies or their comparison with the developed countries. In some studies, the data was used exclusively on the areas in a developed country such as USA. Some other studies have not individually analyzed the developed countries and incorporated the data on the emerging and developed economies to analyze the process of economic convergence (Hussain et al., 2018; Baltgailis, 2019). Overall, the studies analyzing the economic convergence in the developing countries are rate. Particularly, there are fewer researches conducted on the ASEAN countries. The research studies have used information of the developed countries and the findings can be applied to the developed countries only. These research findings cannot be applied to the emerging countries to define and elaborate the process of economic convergence. Based on the identified research gap, the developing Africa region has been focused by this research to analyze the process of income convergence between the economies.

The impact of technology diffusion is a key advantage linked with FDI from the developed economies (e.g. Táncošová, 2019; Tvaronavičienè, 2019; Esquivias Padilla et al. 2019). It implies that higher access to advance 
technology enables a poor country to attract high volume of FDI through convergence extension to the per capital income of developed nations. There are fewer research studies explaining the relation of economic convergence and FDI irrespective of the clear association between these two variables. In this regard, this research has made clear contribution to the literature of FDI and economic convergence because of shortage of research on the FDI's convergence effect.

A single time series equation based on the unit root process of testing on mean deviation group series has been used by the research studies analyzing the economic convergence. Some research studies have adopted unit root testing method based on panel data to explain the process of convergence. To study the process of convergence on a small sample of economies, which are closely located and open for each other, it cannot be wise to use time series data based on single equation. There are some drawbacks of using traditional unit root process of panel data. For example, the convergence of panel members to the average of group cannot be clearly discerned to others by these methods. SURADF (Seemingly Unrelated Regression Augmented Dickey Fuller) has been used by this research to analyze the convergence phenomenon, which is another contribution of the study.

\section{Theoretical and Empirical Review}

\subsection{Economic Convergence and Trade}

The relation between level of disparity in per capital income and trade between size member countries of EEC (European Economic Community) was examined by Samargandi, Fidrmuc, and Ghosh (2015). It was highlighted by the researcher that reduction in the degree of disparity in the income level among the ECE countries is linked with the elimination of trade restrictions between the member countries. Moreover, the researcher compared the income differentials of trade liberalization with the pre-liberalization period to signify whether the improvements are caused by trade liberalization or not. The notion that the restructuring by post world war has contribution to economic convergence among the six member countries was analyzed as well. It was revealed by analyzing the disparity between the three economies joining the EEC that these experienced serious disparities and it was eliminated after joining EEC.

The relation between income convergence and trade was analyzed by Campos, Coricelli, and Moretti (2019). Almost 43 countries were covered in the initial sample, which were including the exporters of oil, countries having per capital income less by $25 \%$ of the per capital income of USA in 1960, former communist countries and another sample of 25 economies. Trade groups were formed based on imports and exports for every country out of the new sample of 25 economies. For every group, the parameters of convergence were calculated as the number of countries varied in trade group with a minimum of three to nine for the period of 1960-1985. The purpose of the research was to investigate whether there is any convergence evidence among the countries forming trade with regard to per capital income as compared with the countries, which have not developed trade relations. It was surprising to know that there was the estimate of convergence parameter of less than one for all the groups (based on exports) except one. This reflects convergence. In 16 cases, the parameter of estimate was significant at level of 10 percent for the 24 groups having the estimate parameter lower than one. In the similar way, the estimate of convergence parameter was less than one for 22 groups out of 25 groups (based on imports). In 17 cases, the estimate parameter was significant at level of 10 percent. Moreover, the formation of groups based on the combination of export and import based groups gave similar results.

Most of the groups had the estimate of convergence parameter less than one and it evidenced convergence. In order to analyze whether the highlighted convergence is the result of trade association between the groups or not, 7300 groups were formed randomly for estimate of convergence models. Out of total, 5000 groups included 9 economies and 2300 groups comprised of three economies. It was revealed through the graphing of parameter that there is more divergence as compared with convergence.

Two contributions were made by Campos et al. (2019).The first contribution was in the sense that the research used a simple and new method for the estimation of convergence. The annual dispersion of the variable was 
taken more into the interest. This approach was a developed way of investigation as compared to the primary method of current income regression against the level of income as proposed by Juknys, Liobikiene, and Dagiliūte (2017) and Fukase and Martin (2017). The second contribution was the development of relation between convergence process and trade between the countries, which has been an issue neglected by the literature on convergence.

The literature was extended by another study conducted on the influence of trade on income convergence. It was explored by the study that trade supports economic convergence among the countries through enhancing their access to the capital markets across the globe. It was claimed by the research that the countries participating in trade have greater access to overseas debt keeping in consideration the imperfections of the capital markets internationally. In this way, domestic investments can be financed through more funds to the countries with high returns. The countries can grow in a faster way.

A robust and positive relation between the trade openness and access to external debt (determined by the degree of external liabilities) was documented. A remarkable contribution was made by this research in terms of methodology as compared with other research studies conducted on the relation of trade and economic convergence. The transmission process of the influence of trade on economic convergence between the countries was clear in this research. The parameters of convergence were estimated in most the traditional researches including Samargandi et al. (2015); Chang, (2017) for a group of countries, which were believed to participate in trade. It was found that income convergence is resulted through trade. However, the finding can be misleading in a way that the causation effect of trade to convergence was not necessary meant by convergence in the trade liberalization period.

The relation of positive association between income convergence and international trade is one aspect. The level of variation in the reduction of income gap among the economies because of the level of trade between them is another aspect. A study was carried out by Santos-Paulino, DiCaprio, and Sokolova (2019) to explore the reduction level in income gap between the countries due to growth in international trade. Based on the data of export and imports, 127 pairs of the economies were made using the data on bilateral trade. It was revealed through the results of the study that with the increase in intensity of trade, the convergence is enhanced between the countries. The result of the study is in line with the pairings based on imports and exports.

GMM estimation process was used by Githuku, Omolo, and Mwabu (2018) to analyze the influence of trade liberalization on convergence of real income between 36 countries in the region of Asia, Africa, and Latin America. Moreover, the two estimates of sigma convergence were computed in addition to the beta convergence. These two measures included deviation from the regional mean and standard deviation of real per capital income. By adopting the approach of single difference and difference in difference, mixed results were found. The convergence in pre and post liberalization was compared in the approach of Single difference. Alternatively, the pre and post liberalization was compared in 'difference-in-differences' method for the economies under research and a control group. The results drawn from the approach of single difference was emphasized because of the difficulty involved in the formation of control group, which confines the heterogeneity between the three regions involved in the study.

Results from Githuku et al. (2018) indicated that there is no significant difference in terms of absolute convergence between pre-liberalization and post liberalization periods for Asia and Latin America. Conversely, for Africa, there appears to be a beta divergence for the periods characterized by trade liberalization. Moreover, the results for sigma convergence are as well mixed. While it was found that there is huge improvement in terms of sigma convergence during post-liberalization periods for the Asian and Latin American countries, liberalization periods are characterized by divergence in the case of ASEAN countries.

In a more recent study, author contributed to the existing body of literature on the relationship between trade and growth by exploring the link between bilateral trade and reduction in income gap. The main objective of the paper was to examine whether with the increase in the intensity of trade between two countries the income 
gap between the countries tends to diminish. To achieve the set goal, Choi utilized bilateral data for 63 countries and 62 exporting partners of each country for the periods 1970, 1980, 1990 and 1992. Employing both pooled OLS and random effects panel regression models, results from the research provide additional support for the positive link between bilateral trade and reduction in income gap. In addition, the research reveals the bilateral trade effect on convergence to be more pronounced when the two countries share same language and are located closely. The author therefore concludes that that the mechanism via which bilateral trade aid convergence between two countries is transfer of knowledge, which in turn depends on geographical proximity and common language.

According to Trofimov (2018), there is the possibility of a reverse causality from income convergence to liberalization and trade. In his view, there is the tendency for the countries that are similar in terms of income to liberalize and as a consequence trade more with one another. In his opinion, this possibly therefore calls for undertaking research from the view point of income convergence causal effect on trade and liberalization. In line with this argument advanced conducted a research to investigate whether the argument is a valid one.

Using disaggregated bilateral trade data for a large sample of 165 countries for the years quinquennial years between 1965 and 2000 the author reported a couple of finding. One, evidence of a bi-directional causality between trade in differentiated and reference-priced sectors was discovered. On the contrast, the causality runs from trade to income convergence when data on trade in homogenous product is used. In line with his findings, the researcher therefore concludes that there is evidence that trade induces income convergence.

A careful survey of studies conducted on absolute convergence would reveal that such studies relied basically on cross-section data. On the other end, majority of studies investigating on sigma convergence have utilized panel data regression. However, recent researches have shown some sort of inclination towards time-series approaches to investigating 'sigma convergence' in what is referred to as 'stochastic convergence'. One of the studies carried out using time-series methodology is Huang, Zhu, Du, and Lee (2016); Cossiga, (2018). The researcher explored on the convergence in per capita output of New Zealand and each of her four major trade partners - Australia, Japan, the UK and the USA. Using both bivariate and multivariate time-series approaches on the data covering $1950-1992$, the author reported a number of findings.

In the case of bivariate approach, using difference between a pair series both ADF and KPSS tests were carried out to test for 'stochastic convergence'. As revealed by the ADF test, there exist a stochastic convergence in output between Japan on one hand, and the UK and the USA on the other. As opposed by the ADF test, results from KPSS test suggest some evidence of stochastic convergence in the output levels of Australia the USA was observed. Moreover, in order to test for the existence or lack of thereof stochastic convergence in the series for the group of countries, the Johansen likelihood ratio 'trace test' was employed. As for this test, the outcome reveals no evidence of stochastic convergence.

Following Huang et al. (2016), similar study was undertaken by Musa (2016). The study involves forming three clusters from a sample of 88 economies. The clusters were formed on the basis of the degree (high, medium and low) of openness of the countries. Using both ADF (drift and trend version) and KPSS tests, unit root tests were carried out on the series of the difference between per capita output of each country and that of the leading country for the three clusters. Although the results from such tests turn out to be mixed, on the balance, there is more of evidence in support of convergence than its absence.

Bivariate analysis of convergence for the three clusters indicates that the high openness cluster comprising of Luxembourg as the leader and 16 other countries has the highest percentage of countries converging to the per capita output of the leader. However, the corresponding percentages for the medium openness and low openness clusters are 40 percent and 45 percent respectively. On the other hand, multivariate stochastic convergence test between groups of economies under each cluster was carried out by employing Ghysels and Miller (2015) "trace test'. Moreover, the outcome of multivariate analysis appears to be a sort of affirmation of the bivariate analysis. 
Conversely, Raychaudhuri and De (2016); De, (2018) holds countervailing view on the impact of international trade and income convergence across countries. The author is of the view that an extra caution should be exercised in concluding that international trade is a catalyst for income convergence among countries. As noted by Slaughter, the leading papers that investigated on the relationship between international trade and income convergence across countries suffer a number of methodological weaknesses. For instance, in studying the impact of trade on convergence across countries, reduction in income disparity among countries during a given period characterized by trade barriers removal should not be enough to justify that trade has any impact on growth. Instead, there is a need to carry out the studies from causation methodological point of view. Therefore, the fact that there is whole range variables believed to have some impact on income convergence, income convergence after trade liberalization among countries does not necessarily connote that trade is the cause.

Moreover, Raychaudhuri and De (2016) highlighted that the proposition that free trade among nations brings about factor prices equalization does not necessarily translate to income convergence among countries. Slaughter further pointed to the fact that Factor Price Equalization (FPE) theorem is built upon very strict assumptions in such a way that a slight change can render the theory invalid. Giving this problem associated with the theorem, even though factor price equalization may result to income convergence, it is difficult to simply attribute income convergence among countries to trade liberalization.

Most of the studies linking trade to income/growth convergence have used single comparison of at most two groups of countries. Contrary to this popular approach adopted 'differences-in-differences' methodology to investigate on liberalization impact of income convergence among liberalizing economies. As opposed by many studies reporting positive impact to liberalization on growth, Slaughter document a negative impact. Analyzing four different post-1945 trade liberalization episodes, the author found that liberalization has divergence effect on income rather than convergence. This result was found in both 'single difference' approach and 'differencein-differences approach and each of the four liberalization episodes the study covered.

\subsection{Government size (GSIZE) and Economic Convergence}

The effect of GSIZE on ECG and economic convergence amongst economies revolves around its link to capital accumulation process. Moreover, by whatever measure of GSIZE (Sagongo et al., 2019), economies differ in terms of GSIZE. Such differences may have some impact on the capital accumulation capacity of the economies and by extension convergence process amongst world economies. However, minds of scholars are divided regarding the nature of the relationship between GSIZE on one hand and ECG and convergence on the other.

As highlighted in Afonso and Jalles (2016), theoretically, the view that larger GSIZE is detrimental to ECG is justifiable by the fact that government operations are to a larger extent commonly undertaken with high degree of inefficiency which translates into low productivity and growth. In addition, larger GSIZE is associated with excessive cost relating to regulatory process thereby exposing the whole economic system to a severe burden. At the other end, some scholars maintain the view that GSIZE is beneficial to economies. To these scholars, larger GSIZE play significant roles that are capable of boasting ECG. According to these scholars, among many justifications of positive link between larger government and ECG is that larger governments play a vital role of preventing exploitation of country by foreigners.

Scholar examines the effect of GSIZE on ECG via its role on capital accumulation. Employing two-way fixed effects regression model on the data covering a total of 57 OECD and non-OECD economies, the author finds evidence that GSIZE hampers ECG mainly by hindering capital accumulation. Examining the effect of GSIZE on ECG via the channel of capital accumulation for the sample of OECD and non-OECD economies separately, the author observes the negative effect of GSIZE on capital accumulation to be persistent only for the sample of non-OECD economies. The author therefore concludes that, as opposed to the situation of developed nations, public sector crowds out private sector in developing economies. In a related effort, Nordin, Mawar, and Zainudin (2019) probe on the effect of GSIZE on ECG using a sample of G-7 countries for the period 1960-1993. Findings emanating from the study show evidence that ECG has both long run and short run effects on GSIZE. 
In a related study, Tran, Drew, and Noguchi (2018) explores the effect of volatility and composition of government expenditure and revenue on ECG of OECD and EU countries. Interestingly, findings from Afonso and Furceri are in line with. Afonso and Furceri observe that each of the components of government expenditure employed in the study to examine the effect of GSIZE on ECG of EU and OECD member economies turns out to show negative and statistically significant effect of government expenditure on ECG.

Nguyet and Phung (2018) also use data from 19 OECD member countries to examine whether GSIZE plays any significant role in explaining the differences in output growth of the sampled economies. Utilizing random effects model on the data spanning 1971 - 1999, the author come up with the conclusion that GSIZE is generally detrimental to ECG amongst sampled economies. Literature on the link between GSIZE and ECG and convergence is dominated by studies undertaken mainly using data from developed economies.

However, of the few studies carried out using data from developing economies is Afonso and Jalles (2016); Edeme, (2017). The study examines the effect of GSIZE on ECG disaggregating the sample based on economic system with the view to probe whether the relationship depends on the type of economic system. Using data from 51 middle income economies over the course of 1960 - 1985, the author reports findings suggesting adverse effect of GSIZE on ECG and productivity and by extension economic convergence. Moreover, the study examines discovers that the negative effect of GSIZE on ECG is more pronounced in countries with nondemocratic socialist system compared to economies with democratic market system.

In the view of Hajamini and Falahi (2018), studies on the impact of GSIZE on ECG, and by extension economic convergence, are commonly plagued by serious econometric problems. In a bid to provide more robust findings regarding the nature of the relationship between the variables, the authors employ extreme bound analysis on data mainly from a sample of rich economies covering the period $1970-1995$. Findings from the study appear to affirm the view that GSIZE is detrimental to ECG.

Another study carried out using data on developing economies only is Agostino, Dunne, and Pieroni (2016). The study utilize data on a sample of 43 developing economies over the course of 20 years. One of the contributions of the study is that it investigates the effect of disaggregated government spending on ECG. Contrary to the findings reported in the teeming majority of the studies that GSIZE has negative effect on growth and economic convergence, Agostino et al. (2016); Elshamy, \& Ahmed, (2017), find positive and significant relationship between GSIZE, as measured by recurrent expenditure, and ECG. On the contrast, the authors observe that there is negative impact of capital expenditure on ECG. The study therefore suggests that previous studies have found negative effect of GSIZE on ECG due using aggregated measures of GSIZE (Ciocchini, 2017; Coccia, 2017). In line with their findings, the authors recommend governments in developing economies should pay much attention in making appropriate allocation of expenditure to ensure ECG and convergence to the output of relatively richer economies.

\subsection{Population Growth and Economic Convergence}

Of the implications of Solow (1956) growth model is the proposition that economies tend to convergence in terms of real GDP per capita in absolute terms providing they are similar in terms of savings propensity, technology and population growth. However, economies vary in terms of population growth rates. This leads to the emergence to the term of conditional convergence. According Solow growth model, an increase in population growth rate of a country causes an increase in the break-even level of investment, which in turn leads to lower steady state level of capital.Studies on the determinants of ECG and by extension economic convergence have commonly included population growth rate as one of the determinants of ECG and convergence. For instance, in the words of Caselli, Esquivel, and Lefort (1996) "there is by now both a strong theoretical case and solid empirical support for the view that ECG affects the population growth rate".

Pioneer among the studies that consider population growth rate as one of the important variables in determining ECG and convergence is the work of Dowrick and Nguyen (1989). The study utilize data for a large sample of 
OECD economies over the period 1950 - 1985. Using OLS to regress 1950 level of GDP growth rates of sampled economies against annual growth rates, annual population growth rates and a host of other variables the authors report a number of interesting findings. Before controlling for population growth, the authors observe fewer occurrences on convergence across different samples compared to the results obtained after controlling for population growth rates of economies. This finding therefore implies that population growth rate plays a vital role in determining economic convergence across economies. Moreover, Grier and Tullock (1989) probe on the effect of seven variables on ECG using cross country regression on a sample of 113 world economies comprising of 24 OECD member economies and 89 other economies. Averaging data over five- year nonoverlapping periods for 24 OECD economies and four observations for each of the remaining 89 economies the authors employ traditional OLS in estimating the relationship of interest. For both OECD and other economies, the researchers find evidence of positive and statistically significant relationship between population growth and initial level of real GDP per capita.

Glaeser, Scheinkman, and Shleifer (1995) explore the link between urban characteristics in 1960 and urban income and population growth rates for the period 1960 - 1990 for a sample of 203 USA cities. The authors observe that there is a positive link between population growth rate and income growth rates amongst USA cities. On the contrast, observes that there is significant negative relationship between population growth and ECG. Similary, Barro (2001) reports a statistically significant negative relationship between output growth and fertility rate. The author therefore concludes that additional population growth rates come at the expense growth rates in real GDP per capita.

Moreover, estimating Cobb-Douglas incorporating growth model for a cross section of world economies, Benhabib and Spiegel (1994) examines the role of human capital in determining cross country variations in ECG. Findings from the study shows that human capital does not significantly determine variations in ECG across countries. Using the growth rate of total factor productivity as an alternative measure of ECG, Benhabib and Spiegel (1994) find evidence in support of positive relationship between human capita and ECG. Galor and Weil (1993) examines the relationship between fertility rate and capital and output per worker. Results from the study indicate that there is positive feedback from low fertility rate to the growth in output and capital per worker.

Traditional unit root testing procedure developed by Dickey and Fuller (1979) is employed to test for convergence hypothesis. Employing ADF test also serves two purposes: 1) the methods has to be used to provide input for performing simulations to apply SURADF procedure. The RATS codes for performing SURADF test for unit root requires using single equation ADF coefficients as well as the lower triangle variance-covariance of errors obtained by estimating ADF within SUR framework. Finally, besides using single equation ADF output as input for conducting SURADF simulations, using it is deemed important for the purpose of comparing the method with SURADF. Unique to this study, employing SURADF to investigate the phenomena of convergence in ECOWAS would mitigate the problems associated with traditional ADF and other panel unit root testing procedures (Breuer, McNown, \& Wallace, 2001).

Examining the phenomena of absolute convergence among ASEAN countries is another set goal of this research. Achieving this goal obviously requires different approach, methodology wise. Cross section regressionbased studies have utilized what is called 'regression to mean' to examine absolute convergence across countries traditional unit root testing procedure developed by Dickey and Fuller (1979) is employed to test for convergence hypothesis. Employing ADF test also serves two purposes: 1) the methods has to be used to provide input for performing simulations to apply SURADF procedure

\subsection{Modeling economic convergence for ASEAN countries}

Examining the phenomena of absolute convergence among ASEAN countries is another set goal of this research. Achieving this goal obviously requires different approach, methodology wise. Cross section regressionbased studies have utilized what is called 'regression to mean' to examine absolute convergence across countries. 
However, the traditional 'regression to mean' approach has been largely criticized for a couple of drawbacks associated with it. For instance, as contained in Friedman (1992) and Quah and Sargent (1993), the approach is prone to regression to the mean bias. Additionally, cross-section regression approach may not be appropriate for investigating convergence for a small sample of countries (Ben-David \& Bohara, 1997). Moreover, by simply regressing initial per capita income against annual averages of per capita income, cross country regression studies waste a lot of useful information. In view of these, this study employed approach similar to that in Ben-David and Bohara (1997). The model for absolute convergence is shown in equation (1)

$$
\boldsymbol{Y}_{i, t}-\overline{\boldsymbol{Y}}=\emptyset\left(\boldsymbol{Y}_{i, t-1}+\overline{(\boldsymbol{Y}}-\mathbf{1}\right)
$$

where yit represents per capita income in economy $i$ at period $t, \bar{y}$ is the average per capita income for a group of $n$ economies during year $t$. $\varphi$ is the coefficient and the convergence term. A result of $\varphi<1(\varphi>1)$ indicates convergence (divergence). Let $z_{i,}={ }_{t}-\bar{y}_{t}$, Equation (2) becomes

$$
Z_{i, t}=\emptyset Z_{i, t-1} \ldots \ldots \ldots
$$

equation [2], according to Nelson and Plosser (1982), can be presented within the framework of ADF as:

$$
Z_{i, t}=\emptyset Z_{i, t-1}=\sum_{j=1}^{k} \partial_{i, j} \Delta Z_{i, t-1}+\varepsilon_{i, t}
$$

where $\varphi$ is the coefficient of lagged dependent variable, $\mathrm{k}$ is the order of lags included in the equation, $\partial$ is the coefficient of differenced $(\Delta)$ lagged dependent variable. Therefore, it can be observed that test for convergence narrows down to testing for unit root of $\varphi<1$ in Equation (3). $\epsilon$ t is the error term.After estimating Equation [3.22], the null hypothesis $\mathrm{H}_{0}: \beta=0$ is tested against the alternative, $\mathrm{H}_{1}: \beta<0$. The test statistic used in testing the null hypothesis against the alternative is given by the formula.

Following Choi (2004), this study hypothesized that as a particular pair of economies convergence in terms of FDI, the economies tend to converge in terms of real GDP per capita

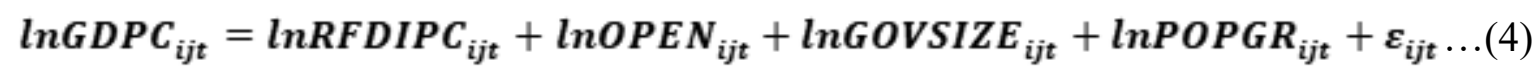

\section{Methodology}

Traditional unit root testing procedure developed by Dickey and Fuller (1979) is employed to test for convergence hypothesis. Employing ADF test also serves two purposes: 1) the methods has to be used to provide input for performing simulations to apply SURADF procedure. The RATS codes for performing SURADF test for unit root requires using single equation $\mathrm{ADF}$ coefficients as well as the lower triangle variance-covariance of errors obtained by estimating ADF within SUR framework. Finally, besides using single equation ADF output as input for conducting SURADF simulations, using it is deemed important for the purpose of comparing the method with SURADF. Unique to this study, employing SURADF to investigate the phenomena of convergence in ECOWAS would mitigate the problems associated with traditional ADF and other panel unit root testing procedures (Breuer et al., 2001). In its generic form, the test assumed the true model to be represented by Equation [5];

$$
Y_{\mathrm{t}}=\alpha+Y_{\mathrm{t}-1}+u_{\mathrm{t}}
$$

The test involves using OLS to estimate Equation [2]. However, Equation [2] is likely to be affected by autocorrelation.

$$
Y_{t}=\alpha+\gamma Y_{t-1}+\delta t+u_{t}
$$


As a remedy to such situation, new version of Dickey-Fuller unit root test was developed. Known as Augmented Dickey Fuller unit root test, the method fits Equation [3].

$$
\Delta Y_{t}=\alpha+\beta Y_{t-1}+\delta t+\beth_{1} \beta Y_{t-1}+\beth_{1} \beta Y_{t-1}+\beth_{1} \beta Y_{t-2} \ldots \ldots \ldots \beth_{1} \beta Y_{t-n}+\varepsilon_{t}
$$

where:

$n$ is the number of lags included,

$\alpha$ is the constant term

$y$ is the series on which test is being performed

$\beth$ is the coefficient of differenced lagged dependent variable

$\delta t$ is time trend

Developed by Blundell and Bond (1998), system GMM uses additional moment conditions to serve as an improvement in terms of performance of estimators in the models developed in Arellano and Bond (1991). System GMM estimator can appropriately country-specific unobserved effects in a situation where the lagged dependent variable is included in a model as a regressors. In addition to handling country-specific unobserved effect, system GMM offers a number of advantages over other static and dynamic panel data estimation techniques. For instance, according to Wooldridge (2002) GMM has the capacity to efficiently take good account of twin problems of serial correlation and heteroscedasticity. Moreover, in the view of Baum, Schaffer, and Stillman (2003), GMM has the advantage of ensuring consistency in the parameter estimates even in the presence of arbitrary heteroscedasticity. Finally, the study is not the first to employ panel GMM in estimating convergence. Studies that employed panel GMM include Weeks and Yao (2003). In the words of Nikoloski (2010), "the difference and system GMM estimators can be seen as part of broader historical trend in econometric practice toward estimators that make fewer assumptions about the underlying data-generating process and use more complex techniques to isolate useful information".

\section{Results}

The variables of primary interest in this study are convergence in real GDP per capita and FDI. Looking at the magnitude and signs of correlation coefficients for the pair of these variables for each of the two sub-samples, a couple of interesting issues can be highlighted (Table 1).

Table 1. Correlation analysis

\begin{tabular}{|c|c|c|c|c|c|c|}
\hline & & $\mathbf{1}$ & $\mathbf{2}$ & $\mathbf{3}$ & $\mathbf{4}$ & $\mathbf{5}$ \\
\hline LRGDP & $\mathbf{1}$ & 1.000 & & & & \\
\hline LFDI & $\mathbf{2}$ & $0.417^{*}$ & 1.000 & & & \\
\hline LOPN & $\mathbf{3}$ & $0.209^{* *}$ & $0.331^{*}$ & 1.000 & & \\
\hline LGOVSIZE & $\mathbf{4}$ & 0.028 & -0.193 & -0.084 & 1.000 & \\
\hline LPOP & $\mathbf{5}$ & 0.041 & 0.045 & $0.051^{*}$ & $0.015^{*}$ & 1.000 \\
\hline
\end{tabular}

** and * represents significance at $5 \%$ and $10 \%$ levels of significance respectively.

Having generated the real GDP per capita deviation series $(y i-\bar{y} t)$ for each economy, the next step involves performing unit root test for each of the deviation series for each economy. Rejecting the null hypothesis that the series does not contain a unit root supports convergence. In order to justify the assertions made regarding the superiority of SURADF as against traditional ADF as well as other techniques for performing unit root test, results for traditional ADF test for stationarity were reported alongside the chosen SURADF for each of the 5 series. Results for the tests on deviation series from ECOWAS average real GDP per capita are presented in Table 2. 
Table 2. Seemingly Unrelated Regression Based Augmented Dickey-Fuller Unit Root Test.

\begin{tabular}{|c|c|c|c|c|c|}
\hline $\boldsymbol{y}_{\boldsymbol{i}}-\overline{\boldsymbol{y}} \boldsymbol{t}$ & \multicolumn{2}{|c|}{$\boldsymbol{t}$-statistic } & \multicolumn{3}{c|}{ SURADF critical values } \\
\hline & ADF & SURADF & $\mathbf{0 . 0 1}$ & $\mathbf{0 . 0 5}$ & $\mathbf{0 . 1 0}$ \\
\hline$\left(y_{i}-\bar{y} t\right)$ Indonesia & $-1.748[1]^{*}$ & $-3.974[1]^{*}$ & -3.404 & -2.399 & -1.804 \\
\hline$(y i-\bar{y} t)$ Malaysia & $-2.073[1]^{*}$ & $-3.150[1]^{*}$ & -4.140 & -3.047 & -2.451 \\
\hline$\left(y_{i}-\bar{y} t\right)$ Thailand & $-2.111[1]^{*}$ & $-1.624[1]^{* *}$ & -2.858 & -1.997 & -1.509 \\
\hline$\left(y_{i}-\bar{y} t\right)$ Singapore & $-1.526[2]^{* *}$ & $-1.570[2]$ & -4.381 & -3.268 & -2.707 \\
\hline$(y i-\bar{y}$ Philippine & $-0.874[1]$ & $0.138[1]$ & -4.149 & -3.062 & -2.495 \\
\hline
\end{tabular}

Note:

a) * and ** indicate rejection of the null hypothesis that real per capita GDP of a particular economy is not converging to the group average at $5 \%$ and $10 \%$ levels of significance, respectively.

b) numbers in brackets represent the lags included to ensure that serial correlation is removed.

c) the critical values for ADF test statistic are: 2.423 , for $1 \%$ level of significance; 1.684 , for $5 \%$ level of significance; and 1.303 , for $10 \%$ level of significance.

d) critical values for SURADF are generated by Monte Carlo simulation using 10,000 replications based on the underlying dataset.

As opposed to the case of nine countries mentioned above, the null hypothesis of no- convergence cannot be rejected in four cases.

Table 3. GMM

\begin{tabular}{|c|c|}
\hline Variable & Model 4 \\
\hline $\operatorname{lnRFDPIC}$ & $0.057[0.017]^{*}$ \\
\hline $\operatorname{lnOPEN}$ & $0.459[0.036]^{*}$ \\
\hline $\operatorname{lnGOVSIZE}$ & $-0.033[0.025]$ \\
\hline $\operatorname{lnPOPGR}$ & $-0.406[0.099]^{*}$ \\
\hline Sargan $(p$-value $)$ Test & $10.596(0.645)$ \\
\hline AR $(1)$ test & -1.322 \\
\hline AR $(1)$ test & 0.122 \\
\hline
\end{tabular}

$* *$ and $*$ represents significance at $5 \%$ and $10 \%$ levels of significance respectively.

The findings in the table 3 indicates that the additional control of population growth does not change the sign of the variable of interest. The estimated parameter is positive and statistically significant at 5 percent level of significance. According to the estimated parameter, one the average, a one percent decrease in the deviation of an economy from group average FDI is leads to 0.057 percent fall in the deviation of the economy from group average real GDP per capita. As for the control variables, positive and statistically significant relationship at 5 percent level of significance was discovered to exist between trade openness and government size on one hand and convergence in real GDP per capita on the other. The implication of this finding is that economies that are more open in terms of trade and with high level of government participation are more likely to show high level of convergence to the group average real GDP per capita than economies that less open to trade with little government participation as measured by government final consumption expenditure as a percentage of GDP.

\section{Conclusion}

There are several studies conducted on the process of convergence in the economy. Most of the previous research studies are based on the emerging economies or their comparison with the developed countries. In some studies, the data was used exclusively on the areas in a developed country such as USA. Some other studies have not individually analyzed the developed countries and incorporated the data on the emerging and devel- 
oped economies to analyze the process of economic convergence. Overall, the studies analyzing the economic convergence in the developing countries are rate. Particularly, there are fewer researches conducted on the ASEAN countries. The research studies have used information of the developed countries and the findings can be applied to the developed countries only. These research findings cannot be applied to the emerging countries to define and elaborate the process of economic convergence. Based on the identified research gap, the developing Africa region has been focused by this research to analyze the process of income convergence between the economies. The literature was extended by another study conducted on the influence of trade on income convergence. It was explored by the study that trade supports economic convergence among the countries through enhancing their access to the capital markets across the globe. It was claimed by the research that the countries participating in trade have greater access to overseas debt keeping in consideration the imperfections of the capital markets internationally. In this way, domestic investments can be financed through more funds to the countries with high returns. The countries can grow in a faster way. A robust and positive relation between the trade openness and access to external debt (determined by the degree of external liabilities) was documented. A remarkable contribution was made by this research in terms of methodology as compared with other research studies conducted on the relation of trade and economic convergence. The transmission process of the influence of trade on economic convergence between the countries was clear in this research. The parameters of convergence were estimated in most the traditional researches including Samargandi et al. (2015) for a group of countries, which were believed to participate in trade. It was found that income convergence is resulted through trade. However, the finding can be misleading in a way that the causation effect of trade to convergence was not necessary meant by convergence in the trade liberalization period.

\section{References}

Adhikary, B. K. (2017). Factors influencing foreign direct investment in South Asian economies: A comparative analysis. South Asian Journal of Business Studies, 6(1), 8-37. https://doi.org/10.1108/SAJBS-10-2015-0070

Afonso, A., \& Jalles, J. T. (2016). Economic performance, government size, and institutional quality. Empirica, 43(1), 83-109. https:// doi.org/10.1007/s10663-015-9294-2

Agostino, G., Dunne, J. P., \& Pieroni, L. (2016). Government spending, corruption and economic growth. World Development, 84, 190-205. https://editorialexpress.com/cgi-bin/conference/download.cgi?db_name=CSAE2016\&paper_id=1095

Arellano, M., \& Bond, S. (1991). Some tests of specification for panel data: Monte Carlo evidence and an application to employment equations. The Review of Economic Studies, 58(2), 277-297. http://people.stern.nyu.edu/wgreene/Lugano2013/pg/Arellano-Bond.pdf

Baltgailis, J. (2019). The issues of increasing the effectiveness of teaching comparative economics. Insights into Regional Development, 1(3), 190-199. https://doi.org/10.9770/ird.2019.1.3(1)

Barro, R. J. (2001). Education and economic growth. The contribution of human and social capital to sustained economic growth and well-being, 14-41. http://www.oecd.org/innovation/research/1825455.pdf

Baum, C. F., Schaffer, M. E., \& Stillman, S. (2003). Instrumental variables and GMM: Estimation and testing. The Stata Journal, 3(1), 1-31. file://C:/Users/Manuela/Downloads/sjart_st0030.pdf

Bayham, A. (2016). A Measurement of Annual GDP Performance of the 162 WTO Members between 1989-2001 and $2002-2014$. Economy, 3(2), 51-73. https://doi.org/10.20448/journal.502/2016.3.2/502.2.51.73

Bayham, A. (2016). An Analysis of the Economic Performance between Nations that made up the 2004 Enlargement of the EU. Economy, 3(2), 79-93.

Ben-David, D., \& Bohara, A. K. (1997). Evidence on the Contribution of Trade Reform Towards International Income Equilization. Review of International Economics, 5(2), 246-255.

Benhabib, J., \& Spiegel, M. M. (1994). The role of human capital in economic development evidence from aggregate cross-country data. Journal of Monetary Economics, 34(2), 143-173. https://doi.org/10.1016/0304-3932(94)90047-7

Blundell, R., \& Bond, S. (1998). Initial conditions and moment restrictions in dynamic panel data models. Journal of econometrics, 87(1), 115-143. http://dx.doi.org/10.1016/S0304-4076(98)00009-8

Boateng, A., Hua, X., \& Nisar, S. (2015). Examining the determinants of inward FDI: Evidence from Norway. Economic Modelling, 


\section{$47,118-127$.}

Bosupeng, M. (2018). Leading Indicators and Financial Crisis: A Multi-Sectoral Approach Using Signal Extraction. Journal of Empirical Studies, 5(1), 20-44. https://doi.org/10.18488/journal.66.2018.51.20.44

Boutayeba, F. (2017). Estimating the Returns to Education in Algeria. Asian Journal of Economic Modelling, 5(2), 147-153. https://doi. org/10.18488/journal.8/2017.5.2/8.2.147.153

Breuer, J. B., McNown, R., \& Wallace, M. S. (2001). Misleading inferences from panel unit-root tests with an illustration from purchasing power parity. Review of International Economics, 9(3), 482-493.

Chang, P. (2017). The Importance Performance Analysis of Taiwan tourism mobile marketing. Journal of Tourism Management Research, 4(1), 12-16.

Cossiga, G. A. (2018). Signals from the World of Economics. The Price Constant and the Democratic Issue. International Journal of Social and Administrative Sciences, 3(1), 1-21.

Campos, N. F., Coricelli, F., \& Moretti, L. (2019). Institutional integration and economic growth in Europe. Journal of Monetary Economics, 103, 88-104. https://doi.org/10.1016/j.jmoneco.2018.08.001

Ciocchini, P. L. (2017). The Relevance of Criminal Courts in the Global South. Laws, 6(4), 29.

Coccia, M. (2017). A Theory of general causes of violent crime: Homicides, income inequality and deficiencies of the heat hypothesis and of the model of CLASH. Aggression and Violent Behavior, 37, 190-200.

Caselli, F., Esquivel, G., \& Lefort, F. (1996). Reopening the convergence debate: a new look at cross-country growth empirics. Journal of economic growth, 1(3), 363-389.

Choi, C. (2004). Foreign direct investment and income convergence. Applied Economics, 36(10), 1045-1049. https://doi.org/10.1080/ 0003684042000246759

De, A. (2018). Momentum Effect, Value Effect, Risk Premium and Predictability of Stock Returns-A Study on Indian Market. Asian Economic and Financial Review, 8(5), 669-681. https://doi.org/10.18488/journal.aefr.2018.85.669.681

Dickey, D. A., \& Fuller, W. A. (1979). Distribution of the estimators for autoregressive time series with a unit root. Journal of the American statistical association, 74(366a), 427-431. https://doi.org/10.2307/2286348

Dowrick, S., \& Nguyen, D.-T. (1989). OECD Comparative Economic Growth 1950-85: Catch-Up and Conv. The American Economic Review, 79(5), 1010. https://www.jstor.org/stable/1831434?seq=1\#page_scan_tab_contents

Doytch, N., \& Narayan, S. (2016). Does FDI influence renewable energy consumption? An analysis of sectoral FDI impact on renewable and non-renewable industrial energy consumption. Energy Economics, 54, 291-301. https://doi.org/10.1016/j.eneco.2015.12.010

Edeme, R. K. (2017). Analysis of the responsiveness of non-oil exports to fiscal and monetary policy actions.

Elshamy, H. M., \& Ahmed, K. I. S. (2017). Green Fiscal Reforms, Environment and Sustainable Development. International Journal of Applied Economics, Finance and Accounting, 1(1), 48-52. https://doi.org/10.33094/8.2017.11.48.52

Esquivias Padilla, M.A., Handoyo, R.D., Sugiharti, 1., Muryani, M (2019). Production networks under The ASEAN Plus Six. A good deal or a threat? Entrepreneurship and Sustainability Issues, 7(1), 81-91. http://doi.org/10.9770/jesi.2019.7.1(7)

Flora, P., \& Agrawal, G. (2017). FDI and economic growth nexus for the largest FDI recipients in Asian emerging economies: a panel co-integration analysis International Business Strategy (pp. 261-275): Springer.

Friedman, M. (1992). Do old fallacies ever die? : JSTOR.

Fukase, E., \& Martin, W. (2017). Economic growth, convergence, and world food demand and supply: The World Bank. http://documents.worldbank.org/curated/en/519861511794565022/Economic-growth-convergence-and-world-food-demand-and-supply

Galor, O., \& Weil, D. N. (1993). The gender gap, fertility, and growth: National Bureau of Economic Research. https://pdfs.semanticscholar.org/a9e1/7156e11a2aa218ec80807f097d62f304c921.pdf

Ghysels, E., \& Miller, J. I. (2015). Testing for cointegration with temporally aggregated and mixed-frequency time series. Journal of Time Series Analysis, 36(6), 797-816. https://doi.org/10.1111/jtsa.12129 
Githuku, S., Omolo, J., \& Mwabu, G. (2018). Income convergence in the east Asean community. Asean Journal of Economic Review, 6(1), 87-102.

Glaeser, E. L., Scheinkman, J., \& Shleifer, A. (1995). Economic growth in a cross-section of cities. Journal of Monetary Economics, 36(1), 117-143.

Grier, K. B., \& Tullock, G. (1989). An empirical analysis of cross-national economic growth, 1951-1980. Journal of Monetary Economics, 24(2), 259-276.

Hajamini, M., \& Falahi, M. A. (2018). Economic growth and government size in developed European countries: A panel threshold approach. Economic Analysis and Policy, 58, 1-13. https://doi.org/10.1016/j.eap.2017.12.002

Huang, L., Zhu, Q., Du, J. T., \& Lee, B. (2016). Exploring the dynamic contribution behavior of editors in wikis based on time series analysis. Program, 50(1), 41-57.

Hussain, H.I., Shamsudin, M.F., Anwar, N.A.M., Salem. M.A. \& Jabarullah, N.H. (2018). The Impact of Shariah Compliance on the Adjustment to Target Debt Maturity of Malaysian Firms, European Research Studies Journal, 21 (2), 48 - 61. https://www.ersj.eu/ dmdocuments/04.HUSSAIN\%20ET\%20ALL_XXI_2_18.pdf

Juknys, R., Liobikienè, G., \& Dagiliūtè, R. (2017). Sustainability of economic growth and convergence in regions of different developmental stages. Sustainable Development, 25(4), 276-287.

Kurul, Z. (2017). Nonlinear relationship between institutional factors and FDI flows: Dynamic panel threshold analysis. International Review of Economics \& Finance, 48, 148-160. https://doi.org/10.1016/j.iref.2016.12.002

Musa, M. (2016). Economic convergence amongst ECOWAS member countries: The role of foreign direct investment. Universiti Utara Malaysia. http://etd.uum.edu.my/id/eprint/6195

Nelson, C. R., \& Plosser, C. R. (1982). Trends and random walks in macroeconmic time series: some evidence and implications. Journal of Monetary Economics, 10(2), 139-162.

Nguyet, T. B., \& Phung, D. N. (2018). Government Size and Economic Growth in Asia-Evidence from China and Japan. Asian Economic and Financial Review, 8(1), 71-89.

Nikoloski, Z. (2010). Financial Sector Development and Income Inequality: Is there a Financial Kuznets Curve? Available at SSRN 1703224

Nordin, N., Mawar, M. Y., \& Zainudin, N. (2019). Growth effect of foreign direct investment: The role of labor market flexibility. Economic Journal of Emerging Markets, 11(1), 19.

Oduro, S. (2016). The impact of inflation and foreign direct investment on economic growth: evidence from Ghana (1975-2013).

Quah, D., \& Sargent, T. J. (1993). A dynamic index model for large cross sections Business cycles, indicators and forecasting (pp. 285-310): University of Chicago Press.

Raychaudhuri, A., \& De, P. (2016). Trade, infrastructure and income inequality in selected Asian countries: An empirical analysis International Trade and International Finance (pp. 257-278): Springer.

Sasongko, G., Huruta, A.D., Wardani, A. (2019). Does the Wagner's Law exist in a strategic national area? An evidence from Kedungsepur - Indonesia. Insights into Regional Development, 1(2), 99-117. https://doi.org/10.9770/ird.2019.1.2(2)

Samargandi, N., Fidrmuc, J., \& Ghosh, S. (2015). Is the relationship between financial development and economic growth monotonic? Evidence from a sample of middle-income countries. World Development, 68, 66-81.

Santos-Paulino, A. U., DiCaprio, A., \& Sokolova, M. V. (2019). The development trinity: How regional integration impacts growth, inequality and poverty. The World Economy, 42(7), 1961-1993. https://doi.org/10.1111/twec.12788

Simionescu, M. (2016). The relation between economic growth and foreign direct investment during the economic crisis in the European Union. Zbornik radova Ekonomskog fakulteta u Rijeci: časopis za ekonomsku teoriju i praksu, 34(1), 187-213. https://doi. org/10.18045/zbefri.2016.1.187

Solow, R. M. (1956). A contribution to the theory of economic growth. The quarterly journal of economics, 70(1), 65-94.

Táncošová, J. (2019). The role of foreign direct investment in the economy of Slovakia. Entrepreneurship and Sustainability Issues, 6(4), 2127-2135. http://doi.org/10.9770/jesi.2019.6.4(40) 
Tran, T. V., Drew, J., \& Noguchi, M. (2018). The Role of Revenue Volatility in Local Expenditure Volatility: A Comparison of Tokyo Metropolitan Local Governments. Economic Papers: A journal of applied economics and policy, 37(4), 443-455.

Trofimov, I. D. (2018). Income terms of trade and economic convergence: Evidence from Latin America. https://mpra.ub.uni-muenchen. de/id/eprint/87598

Tvaronavičienè, M (2019). Insights into global trends of capital flows' peculiarities: emerging leadership of China. Administratie si Management Public, (32), 6-17. http://doi.org/10.24818/amp/2019.32-01

Weeks, M., \& Yao, J. (2003). Provincial conditional income convergence in China, 1953-1997: a panel data approach. Econometric Reviews, 22(1), 59-77. https://doi.org/10.1081/ETC-120017974

Wooldridge, J. M. (2002). Inverse probability weighted M-estimators for sample selection, attrition, and stratification. Portuguese Economic Journal, 1(2), 117-139.

\section{Marlina WIDIYANTI}

Faculty of Economics, Universitas Sriwijaya, Palembang, Indonesia. Marlina Widiyanti is Associate Professor of Financial Management and Strategic Management at Departement of Management in Economic Faculty, University of Sriwijaya. Research interests: Finance Management, Strategic Management, Banking Syariah Management, Human Resources, Marketing Management and Public Sector Management https://orcid.org/0000-0003-0431-814x

\section{Ernie HENDRAWATY}

Faculty of Economics and Business, Universitas Lampung, Bandar Lampung, Indonesia.

Ernie Hendrawaty is Assistant Professor of Finance at Department of Management in Faculty of Economics and Business, Universitas Lampung, Lampung, Indonesia. Research interests: Corporate Finance, Consumer Finance, Investment Management, Corporate Governance.

\section{DJAWOTO}

Faculty of Management, Indonesia School of Economics Surabaya, Surabaya, Indonesia. Djawoto is the Associate Professor of Marketing Management at Departement of Management; Economis and Business Faculty: Indonesia School of Economics (STIESIA) Surabaya. Research interests: Marketing Management Strategic Management, Public Finance, and Human Resources. https://orcid.org/0000-0002-7755-2773

Register for an ORCID ID:

https://orcid.org/register

This work is licensed under the Creative Commons Attribution International License (CC BY). http://creativecommons.org/licenses/by/4.0/ 